\title{
Kunstkammeret som dannelsesritual
}

\author{
HeLene IlLeris*
}

Title: Educational rituals at The Royal Danish Kunstkammer.

Abstract: In the fifteenth and sixteenth century The Royal Danish Kunstkammer provided the framework for two different educational rituals, one aimed at the court and another aimed at visitors from outside. The article employs an educational-anthropological perspective to investigate how the Kunstkammer's spatial organisations favoured certain movement and perception.

Keywords: Kunstkammer, education, ritual, spatial organizations, performance, ways of seeing.

FREDERIK III'S KUNSTKAMMER- OG BIBLIOTEKSBYGNING

I årene 1665-1673, kort efter enevældens indførelse i Danmark, lod Frederik d. III opføre en storslået kunstkammer- og biblioteksbygning $\mathrm{i}$ tre etager mellem Kavalergården ved sydvestsiden af det daværende Københavns Slot og Tøjhushavnen ${ }^{1}$. Bygningen, som i dag huser Rigsarkivet, havde fra starten ${ }^{2}$ en grundplan på 138 x 21 Alen (ca. 13 x 87 m.). Den smalle og lange form tillod en konstruktion med store åbne rum uden tværmure til at bære etageadskillelserne mellem første og anden etage (Mogensen 2001).

Ved opførelsen var hovedfacaden mod slottet antagelig beklædt med røde hollandske mursten, og som noget ganske nyt og bekosteligt blev taget belagt med kobber (fig. 1). Som eneste udsmykning havde man på tagryggen placeret to mandshøje ${ }^{3}$ bemalede og forgyldte egetræsfigurer af Minerva og Mars (Schiøtt 1908: 15). Den nye bygning er senere blevet beskrevet som en konstruktion "i den tidlige klassiske baroks mest knappe formsprog" (Villadsen 1998: 28), der "på samtiden må have virket som et vidunder af regelmæssighed og enkelhed, med sine relativt få, store vinduer og ubrudte murflader" (Lund 1996: 214).

Indvendigt afspejlede de tre etager en funktionsopdeling, der var kendt fra andre fyrstehoffers bygningskomplekser: i stueetagen indrettede man tøjhuset, på den fornemme første sal var bogsalen og på anden salen Kunstkammeret $^{4}$ (fig. 2). På den måde havde man "hele verden" under samme tag: Ars, Lex og Mars, som der skal have stået på en plade, der prydede facaden.

Med den nye bygning fik Frederik III's kunstkammer, som hidtil havde haft til huse på Københavns Slot, en hel etage til rådighed, og blev nu for alvor et sted, hvor tidens fyrste- 


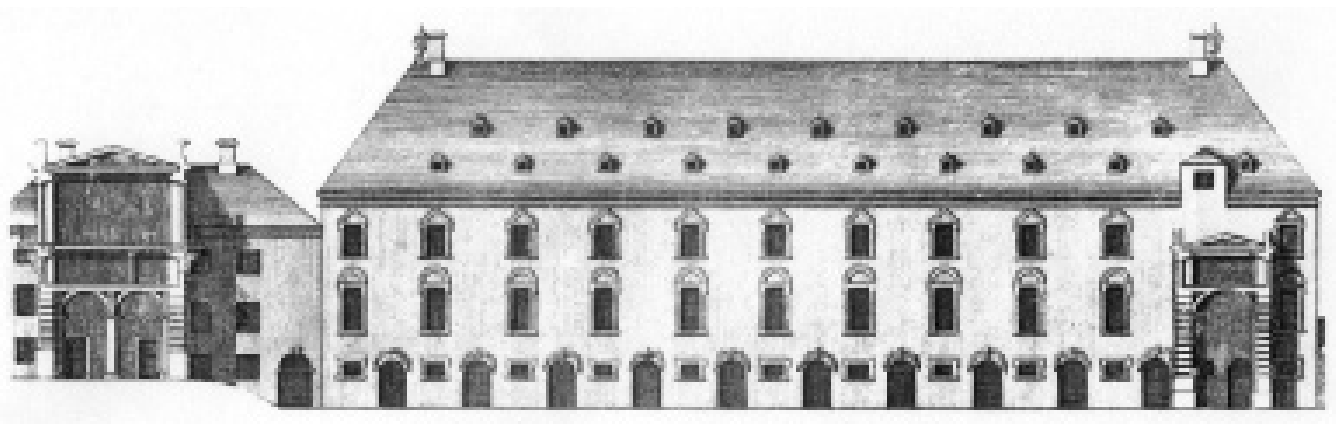

Fig. 1. Biblioteks- og Kunstkammerbygningen. Stik fra Laurids de Turah: Hafnia Hodierna. Kiøbenhavn 1748. På tagryggen anes de to mandshoje figurer af Minerva og Mars.

lige ritualer for samling og fremvisning kunne implementeres ${ }^{5}$. Her kunne såvel hoffets medlemmer som besøgende udefra hellige sig oplevelsen af denne verdens mest exceptionelle frembringelser i passende omgivelser og uden forstyrrelser. Ikke helt ulig de offentlige museer, vi kender i dag, kunne man tale om "the achievement of a marked off, 'liminal' zone of time and space in which visitors, removed from the concerns of their daily, practical lives, open themselves a to a different quality of experience" (Duncan 1995: 20).

\section{MUSEUMSFORMIDLING SOM RITUAL}

En af udfordringerne i vore dages samfund er, at vi i stigende grad stiller spørgsmålstegn ved de ritualiserede former for social praksis, der kendetegner modernitetens institutioner, herunder skolen og museet (Illeris 2003). Denne tilsyneladende afritualisering har store konsekvenser for vores måde at tænke formidling på, fordi den medfører en relativering af vores forestilling om institutionernes pædagogiske formål.
På det kunst- og billedpædagogiske område er de ritualiserede iscenesættelser, der ofte kendetegner kunstmuseernes formidling, blevet problematiseret fra flere sider, hvilket mange steder har ført til eksperimenter med nye former, både når det gælder omvisninger og andre typer af formidling i udstillingerne. I modsætning til den traditionelle omvisnings disciplinering af publikums blik, ønsker mange kunstmuseer nu at stimulere et blik, som tager udgangspunkt $\mathrm{i}$ den besøgendes personlige interesse og fascination. Hermed afløses museets klassiske borgerlige dannelsesideal af en opfordring til selvdannelse og "ansvar for egen læring" (Illeris 2006).

I kølvandet på afritualiseringen er der ikke overraskende opstået en fornyet interesse omkring formidlingens historiske dimension. I min museumspædagogiske forskning har jeg i særlig grad søgt at stille skarpt på, hvorledes forskellige formidlingsritualer og rumlige iscenesættelser har påvirket publikums blik og kropslige performance $\mathrm{i}$ overensstemmelse med forskellige opfattelser af begrebet dannelse (se fx Illeris 2002, 2003, 2006). Nærværende undersøgelse af Kunstkammeret som 
dannelsesritual ${ }^{6}$ indgår som et vigtigt led i denne forskning, fordi Kunstkammeret er et af de første danske udstillingsrum, som er indrettet med et bevidst opdragende sigte (Hein 2002).

Som udgangspunkt for undersøgelsen har jeg hentet inspiration i Carol Duncans bog Civilizing Rituals, inside public art museums (Duncan 1995). Med en synsvinkel hentet fra antropologien sidestiller Duncan her museumsbesøget med deltagelsen $\mathrm{i}$ en rituel handling, en synsvinkel, der ligger tæt op da den, jeg her vælger at anvende på Kunstkammeret $^{7}$. En anden inspirationskilde har været Barbara Stafford's studier af "visual education" i oplysningstiden. Med afsæt i hendes diskussioner kan Kunstkammeret ses som en særlig visuel praksis, hvor 16-1700-tallets dannelsesidealer blev udfoldet og iscenesat i et komplekst samspil mellem visualitet, materialitet og narrativitet, hvilket gav de besøgende mulighed for at positionere sig som "interactive participants in multiple ways of knowing" (Stafford 1994: 286).

\section{DEN HISTORISKE DIMENSION}

En undersøgelse af Kunstkammeret, som det så ud for mere end 300 år siden, må naturligvis have en væsentlig historisk dimension. I løbet af de sidste godt 100 år er der foretaget et betydeligt antal studier af Det Kongelige danske Kunstkammer. ${ }^{8}$ Disse har sammen med en række nyere videnskabelige artikler, publiceret i bl.a. Nordisk Museologi, bidraget til, at vi i dag har en omfattende viden om Kunstkammerets historie. ${ }^{9}$ Nærværende undersøgelse adskiller sig fra de tidligere ved at introducere en pædagogisk antropologisk synsvinkel med særlig fokus på forholdet mellem rum, krop

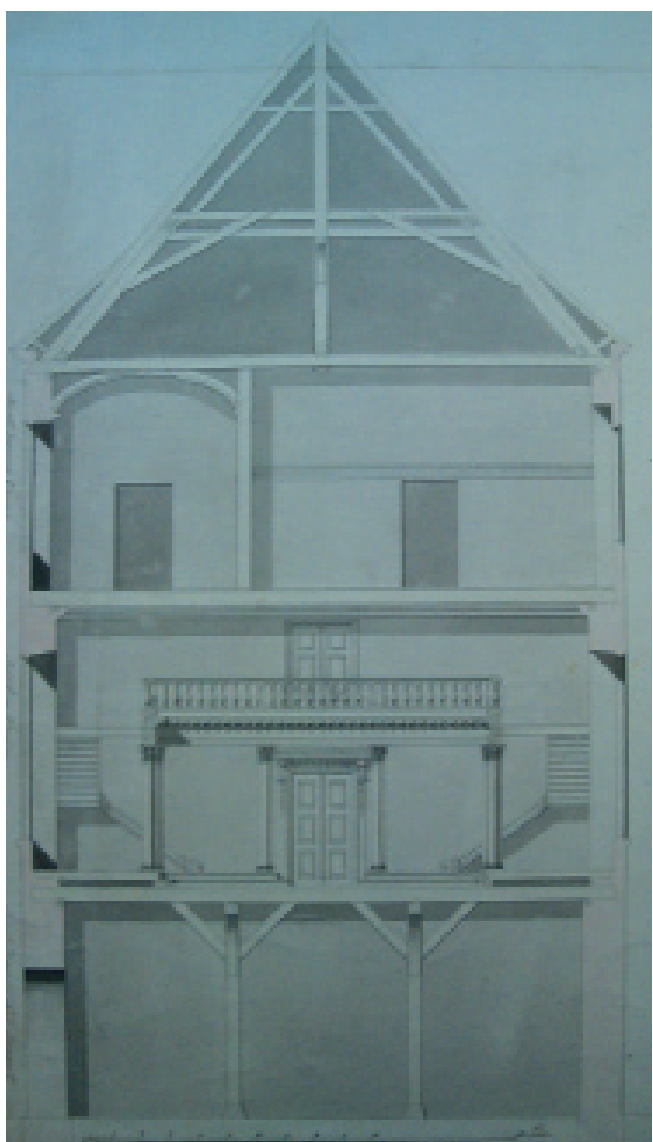

Fig. 2. Biblioteks- og Kunstkammerbygningen. Snit. Ombygningsprojekt. Anders Kirkerup, 1786. Kunstakademiets Bibliotek. Samlingen af Arkitekturtegninger. Snittet viser forholdet mellem bygningens tre etager, hvor tojhuset var placeret $i$ stuen, biblioteket på forste sal og kunstkammeret $p a ̊ a$ anden etage. På kunstkammeretagen ses de hoje vinduer, Galleriets hvalving og salenes lige loft.

og blik. ${ }^{10} \mathrm{Ud}$ fra bl.a. historikerne Ulrik Lange (2002) og Peter Burke (1987)'s antropologisk inspirerede metodologiske overvejelser, vil jeg betone nedenstående punkter i forhold til fremgangsmåden i mine studier: 
62 Udgangspunktet er ikke en intention om at belyse, hvordan det virkelig var for 16-1700 tallets mennesker at besøge Kunstkammeret, men at vise hvilke subjektpositioner og blikformer Kunstkammeret, gennem rummenes og udstillingernes fysiske iscenesættelse, muliggjorde for de besøgende.

2 . Formålet er ikke primært at udbygge vores viden om 16-1700-tallets samfund, men at skabe genealogiske forbindelsestråde mellem historiske og nutidige dannelsesritualer i forbindelse med udstillingsbesøg.

3. Artiklen bygger ikke primært på klassisk kildemateriale i form af samtidige vidnesbyrd, men på en rekonstruktion af Kunstkammerets indretning og fysiske fremtrædelse ud fra visuelt materiale $\mathrm{i}$ form af arkitekturtegninger, fotos af originale og rekonstruerede kunstkamre, afbildninger af genstande, samt eksisterende forskning på området.

\section{RUMLIGE ISCENES/ETTELSER}

Et særligt kendetegn ved Kunstkammerets iscenesættelser var, at det både varetog en intern funktion, rettet mod hoffet, og en ekstern funktion, rettet mod et udefrakommende publikum. Denne dobbelte funktion blev understeget rumligt ved, at man indrettede to sepa- rate indgange i hver sin ende af bygningen: én til hoffet med direkte adgang fra slottet via en løngang og én til andre besøgende med indgang udefra.

Også på selve kunstkammeretagen bidrog de rumlige iscenesættelser til styringen af publikums bevægelsesmønstre. Bl.a. valgte man undervejs i byggeriet at opdele det vældige rum ved at flytte hængesøjlerne ${ }^{11}$ hen mod slotssiden og sætte vægge i "saaledes at der her fremkom et smalt Billedgalleri, mod Tøjhusgaarden derimod en Række dybere Sale" (Schiøtt 1908: 11). I stedet for at tillade publikum at cirkulere frit overalt og beundre de overdådige arrangementer, som det fx var tilfældet i München (Seelig 1985: 81), blev de besøgende herigennem tvunget til at følge fastlagte ruter, hvor galleriet iscenesatte én type oplevelse og salene en ganske anden. Endelig indrettedes der for hver ende af galleriet to mindre kamre, og ved indgangen udefra desuden en forstue, som man kom igennem inden man gik op ad den smalle vindeltrappe. ${ }^{12}$ (Fig. 3).

Hvad selve indretningen angår, var der stor forskel på Galleriet og de øvrige sale. De fem sale har formodentlig været forholdsvis enkelt udstyret: trægulve "paa hollandsk manér" og "almindeligt Bjælkeloft, beklædt paa bjælkerne og mellem disse med Brædder og 'sirlige lis-

Fig. 3. Biblioteks- og Kunstkammerbygningen. Plan. Ombygningsprojekt. Anders Kirkerup, 1786. Kunstakademiets Bibliotek. Samlingen af Arkitekturtegninger. Planen viser vindeltrapperne for hver ende af kammeret, de to sma kamre ved trapperne, Galleriet mod nord og de fem sale mod syd. I modsatning til Bering Liisbergs senere plantegning er proportionerne her baseret på opmålinger, og man ser hvorledes salene havde forskellig storrelse.

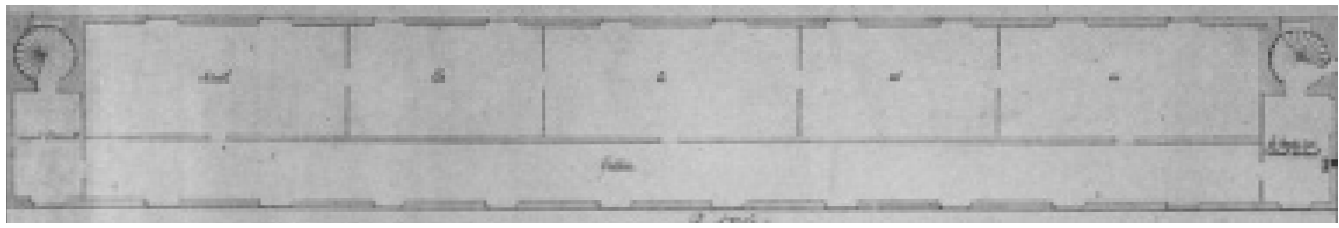


ter” (Liisberg 1887: 110). Farvesætningen kender vi ikke, men det kan være rimeligt at forestille sig ensfarvede vægge. I biblioteket på etagen neden under var lofterne malet hvide og døre og gerichter malet i grå nuancer, hvilket kan have gået igen i kunstkammeretagen (Lund 1996:219), men man kan også forestille sig vægge i samme farver som i de første fire af Frederik III's kunstkammergemakker på Københavns Slot: aurumgult, blåt, zinnoberrødt og grønt. ${ }^{13}$

I salene bestod det vigtigste inventar af skabe, som formodentlig har været bemalet både udvendigt og indvendigt. Ifølge Otto Andrup (1933: 16) var der tilbage fra Frederik III's tid tale om "Smaa Skabe med grønne, blyindfattede Ruder i Dørene". Disse skabe blev dog efterhånden suppleret af andre, som formodentlig har haft gennemsigtigt glas i dørene, som man ser det i fotografierne fra kunstkammeret i Halle (fig. 4) og i rekonstruktionen af kunstkammeret i Innsbruck. ${ }^{14}$ Af yderligere inventar må man ud fra beskrivelser af andre kunstkamre forestille sig, at der har været borde, hvor de lidt større genstande har stået opstillet, og at disse har været udstyret med skuffer til mindre objekter. Desuden viser inventarierne, at der har hængt malerier på væggene i alle rummene, formodentlig over skabene og mellem vinduerne. Endelig har en del større ting været placeret på gulvet, nogle ting har hængt under loftet og endelig kan visse sager, som $\mathrm{i}$ andre kunstkamre, have været opbevaret i kurve (Scheicher 1985, Seelig 1985).

Galleriets indretning og udsmykning var mere overdådig. Her blev loftet udstyret med hvælving med stuk i barok stil udført efter tegning af Thomas Walgensten (fig. 5). ${ }^{15}$ Formodentlig efter inspiration fra italienske og franske forbilleder, ${ }^{16}$ lå hovedvægten i galleriets indretning på luft, lys og graciøs elegance med

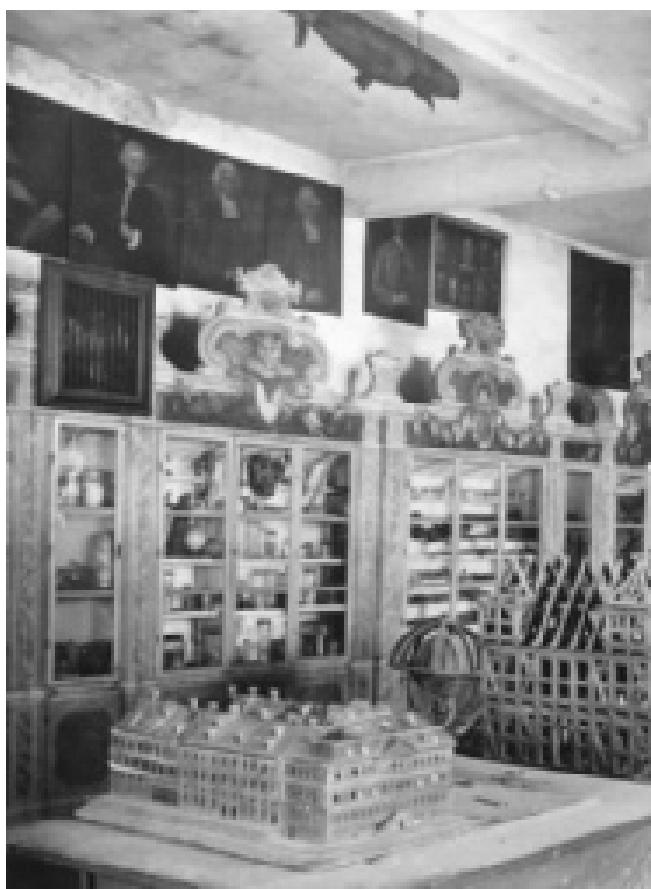

Fig. 4. Kunst-og Naturaliekammeret $i$ Halle, indrettet af August Hermann Francke i 1598. Udsnit af fotografi taget $i$ 1909, da kammeret blev genåbnet efter at have ligget ubenyttet hen $i$ langere tid. Kammerets indretning med skabe langs vaggene, objekter (her bygningsmodeller) placeret pà borde og malerier over skabene kan give en idé om, hvorledes salene i Det danske Kunstkammer kan have taget sig ud. Kilde: Patrick Mauriès, Das Kuriositätenkabinett. Köln 2002.

10 store, nordvendte vinduer, som gav lys til en mere end 70 meter lang ubrudt væg, hvor de vældige "skilderier" hang. Hvor salene blev enkelt indrettet og hierarkisk og tematisk organiseret som en encyklopædisk samling, var der i galleriet tale om en prangende rumtype, der tillod hoffet og de besøgende frit at defilere ned gennem bygningen, mens de beundrede kunstværkerne. 


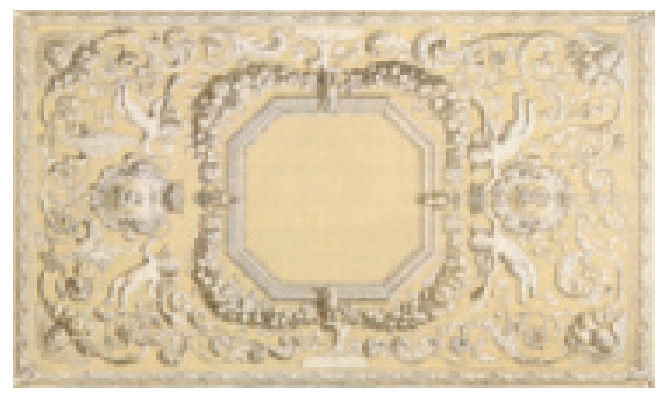

Fig. 5. Stukloftet i bibliotekskabinettet gengivet på litografi fra 1873. Det kan ikke med sikkerhed afgøres om litografiet gengiver dekorationens oprindelige udseende, men de kronede emblemer gengiver Frederik IIIs og hans dronning Sofie Amalies monogram. Det kan antages at stuklofterne i Kunstkammerets Galleri samt Medallieog Perspektivkammeret, som ligeledes var udfort efter tegning af Thomas Walgensten, har haft et lignende barokpreg. Kilde: Det kongelige Bibliotek - et hus på Slotsholmen, udgivet af Det kongelige Bibliotek. København 1993.

\section{SUBJEKTPOSITIONER}

Hvad 'brugerne' angår, kan Kunstkammeret, lidt skematisk formuleret, betragtes som et mødested mellem tre forskellige ritualer med tilhørende positioneringsmuligheder:

- Et internt rettet opbevarings-og studereritual relateret til kongens og hoffets private brug.

- Et internt rettet paraderitual relateret til fremvisningen af de kongelige samlinger for hoffets gæster.

- Et eksternt rettet fremviserritual relateret til formidling af samlingerne for besøgende udefra.

I det følgende vil jeg primært fokusere på paraderitualet, der, som vi skal se, tidligt kom til at dominere over opbevarings- og studereritualet, og på det eksternt rettede fremviserritual. Jeg vil diskutere kammerets positione- ring af hhv. kongen/hoffet og publikum, ud fra de ruter de har fulgt gennem samlingerne, samt hvorledes disse ruter kan have iscenesat krop og blik.

\section{PARAdERItualet}

Under enevælden var kongens krop privilegeret på en måde, der kan være svær at forestille sig i dag. Den blev plejet, udstyret, transporteret, feteret, fremvist, afbilledet, konserveret og udstillet. De bygninger, kongen ejede, og hvori han færdedes, var naturligvis indrettet med henblik på at give hans, hoffets og hoffets gæsters legemer det størst mulige behag. Bl.a. derfor blev kunstkammerbygningen forbundet med Københavns Slot gennem en løngang, den såkaldte Vægtergang, som gik fra biblioteket over provianthuset til slottets første sal, således at kongen, sammen med sine gæster, kunne spadsere direkte fra den ene bygning til den anden. ${ }^{17}$

Set ud fra et ritualteoretisk synspunkt indgik Kunstkammeret som en vigtig del af den ceremonielle konsolidering, som var af stor betydning for opretholdelsen af den tidlige danske enevælde såvel nationalt som internationalt (Olden-Jørgensen 2002). Paraderitualet skulle kaste glans over kongen og hoffet i udvalgte og betydningsfulde gæsters nærvær, og det skulle medvirke til at fremvise Hans Kongelige Majestæt som en værdig og magtfuld leder af en moderne absolutistisk stat.

\section{Kongeruten}

Når kongen og hans gæster kom op ad vindeltrappen, der førte fra bogsalen til Kunstkammeretagen, trådte de først ind i Medalliekammeret, det mest intime af Kunstkammerets rum og samtidig det, der mest var at ligne med et privat studerekammer. Her kunne 
kongen fremvise en type samlerobjekter, som havde relation til renæssancens private, fyrstelige kamre: antikke og moderne mynter og små portrætter og billeder med religiøse motiver, deriblandt "Christi Fødsel", som man tilskrev selveste Raphael. Kammerets mange skuffer, som bl.a. indeholdt møntbakker i læder med guldtryk med romerske dinarer (fig. 6), har kaldt på et ritual omkring stille fordybelse, hvor kroppen skulle holdes i ro og blikket fokuseres. I dette kammer har kongen, lidt tilstræbt måske, kunnet positionere sig i rollen som humanistisk lard med historiske og religiøse interesser.

Fra Medalliekammeret fortsatte kongeruten ind i galleriet, som, i kontrast til det lille rum, må have inviteret til at blive indtaget af kroppe i bevægelse: vandrende, konverserende og beundrende de prægtige malerier. Kongen har her kunnet positionere sig som internationalt orienteret, smagfuld og økonomisk formående kunstelsker.

For enden af galleriet fandtes dørene til perspektivkammeret og til de fem tematiske sale, hvor kongen opbevarede størstedelen af samlingerne. Valgte man at gå gennem salene måtte man følge en hierarkisk ordnet rute gå-

Fig. 6. To små møntbakker, måske fra Frederik III's samling, ilagt romerske denarer med portratter af de 12 kanoniske kejsere fra Casar til Domitian. Nationalmuseet, Den kgl. Mønt- og Medaillesamling.

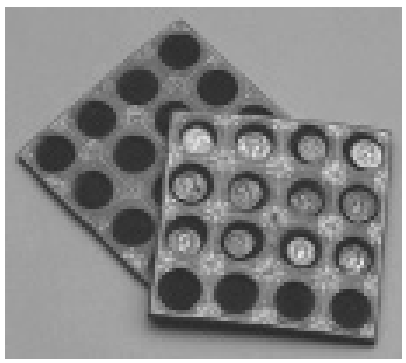

Kilde: www.kunstkammer.dk ende fra Helden Kammer, som "indeholdt kongelige eller andre berømtheders portrætter, malede eller i voks" og videre ned gennem Antiquitet-Kammer, Indiansk Kammer, Artificial Kammer til Natural Kammeret indeholdende "Allehaande Naturens bade rare og monstreuse Producter" 18 (Gundestrup 1991: 36).

I modsætning til galleriets samlede æstetiske udtryk, bar salene præg af det fokus på enkeltgenstande, der bl.a. var karakteristisk for Ole Worms videnskabelige samling, som blev købt af Frederik III i 1654. Her har kongen kunnet positionere sig som en dygtig samler ved at forundre gæsterne med fremvisninger af "rare, kunstige og fortræffelige sager" (Thura 1748/1967: 119). I ordningen af de enkelte skabe og vægge har Kunstkammeret dog, i modsætning til Museum Wormianum, i stigende grad placeret genstandene i større sammenhænge, så de i forhold til paraderitualet kunne fungere som "'samtalestykker', dvs. konkrete anledninger til at fortælle en eksemplarisk historie eller en spændende beretning" (Mordhorst 2003:174) eller som "anledning til åndfuld konversation mellem kongen og hans gæster" (op.cit: 167).

Samlet set har kongeruten gennem Kunstkammerets rumlige sekvenser iscenesat en fortælling om kongens mangfoldige og ypperlige interesser og kvaliteter: lærd og fordybet, smagfuld og storslået, fascineret og videbegærlig. Undervejs i besøget har kroppene måttet performe flere forskellige rytmer: fra det langsommelige studium af mønter og medallier over galleriets frie bevægelsesmuligheder til de moderate bevægelser ved fremvisninger af enkeltgenstande i de tematiske kamre. Desuden har såvel gæsterne som kongen selv haft mulighed for en vekselvirkning mellem forskellige blikformer: et lærd og fordybet blik i Medalliekammeret, et beundrende kenderblik i 
Galleriet og et nysgerrigt og undersøgende blik i salene.

\section{FREMVISERRITUALET}

Det ude fra kommende publikum har i de første 30-40 år efter at Kunstkammeret stod færdigindrettet i 1680 været begrænset i antal, og der har udelukkende været tale om folk med høj status, som dermed var i stand til, formodentlig ved betaling, at opnå den nødvendige kongelige tilladelse. Senest omkring 1720 bortfaldt fordringen om kongelig tilladelse, og de interesserede skulle blot henvende sig til kunstkammerforvalteren, hvis indtjening delvis var afhængig af betaling for rundvisninger. Ved 1700-tallets slutning havde Kunstkammeret i høj grad antaget karakter af seværdighed såvel for tilrejsende som for Københavns rige og veluddannede elite (Nielsen 1988: 44-45).

Nogle af de tidligste beretninger fra besøg på Kunstkammeret stammer fra kunstnere på rejse i 1680'erne, som tilsyneladende ubesværet har fået adgang. Den franske dramatiker J.-F. Regnard (1681/1909) beretter kort og beundrende om de mærkværdigheder, "vi saa", mens den svenske billedkunstner Nicodemus Tessin, som kom forbi på vej til Italien, er ganske uimponeret over galleriet "worinnen ein hauffen Schilderijen wahren, aber de meisten schlecht undt von Modernen Meistern", mens han fandt "die Curiositet zimblich zu admiciren" (Sirén 1914: 62).

Disse beretninger tyder på at tilrejsende, som ikke har været bundet af hoffets etikette, ikke nødvendigvis har ladet sig imponere af de royale iscenesættelser, men snarere som et moderne publikum har forholdt sig på en gang nysgerrigt og kritisk evaluerende til oplevelsen.

\section{Publikumsruten}

Hvor paraderitualerne handlede om at behage og imponere, handlede ritualerne omkring publikum i højere grad om at underholde og belære. Ved sådanne lejligheder har forvalteren ledt de besøgende ind gennem en dør under løngangen til Tøjhuset og ind i forstuen "Allernederst under til Gaden", hvor de fik en slags forsmag på, hvad der ventede. Rummet indeholdt en række interessante sager så som "Een liiden udstoppet Elephant", "Een stor udstoppet Oxe” og "Een ditto Wal-Ross" samt "Radden af een stor Slange" (Gundestrup 1991: 452) og en række malerier bl.a. "af en Ged, som kun havde et Øre, uden spor af det andet; af to indiske Fisk med røde Finner - de vare fangede i Sundet - samt af et menneskeligt kæmpemæssigt Skelet, 24 fod langt” (Liisberg 1897: 111). Allerede forstuen gav således de besøgende mulighed for at positionere sig som forventningsfuldt publikum, med forundrede og spændte blikke på mærkværdighederne.

Efter forstuen bevægede den besøgende sig op i perspektivkammeret, som rummede "Allehaande Kongelige Perpectiv-Stykker", herunder "adskillige skabe hvorudi alle Arter af Kirker, Lutherske, Reformerede og RomanskCatholske og andre Ting kunstig i Perspectiv forestilles" (Thura 1748: 107). Perspektivkammeret synes at have været enestående for det københavnske kunstkammer og havde den vigtige funktion at være "et kostbart skuestykke, som skulle imponere og overraske den besøgende med en kunst, der var helt ny og skelsættende for sin tid" (Pedersen 2005: 83).

Fra Perspektivkammeret kunne man enten starte med at vandre ned gennem Galleriet eller med straks at dreje til venstre og gå ind $\mathrm{i}$ Heltekammeret. Begge rum har understreget 
intentionerne om at skabe ærefrygt: Galleriet som allerede nævnt ved sin størrelse og pragt, Heltekammeret på en mere håndgribelig facon ved fysisk at visualisere kongemagten i form af legemsstore, naturalistiske malerier, buster og voksskulpturer af Europas konger og fyrster (fig. 7).

Herfra gik ruten videre ned gennem de øvrige tematiske sale, hvor beretninger fra tilrejsende tyder på, at det udefra kommende publikum i særlig grad fik forevist genstande, hvortil der knyttede sig de mest dramatiske og overnaturlige historier. Det har også været almindeligt, at man kunne få lov til at røre ved genstandene og evt. afprøve deres funktioner (Nielsen 1988: 36-37). Besøget i salene har således været iscenesat med henblik på at stimulere nysgerrige og undersøgende attituder og blik, hvor det, næsten som i moderne "handson" museer, har været muligt at se, røre, undersøge og spørge.

Samlet set kan publikumsruten forstås ud fra det begreb om "hypervisibilitet", som bl.a. Stafford (1994: 225) har introduceret. Hun beskriver det "glubske blik", der kendetegnede 1700 -tallets voksende borgerstand i relation til forskellige visuelle fænomener, som på den ene eller den anden måde stimulerede såvel skuelysten som videbegæret. Set i dette perspektiv giver det danske kunstkammers publikumsrute mening som kongemagtens mest moderne bud på, hvad man kunne byde publikums blik: først Forstuens pirrende mærkværdigheder og perspektivkammerets ypperlige leg med øjet, herefter Galleriets prangende "gesamtkunstværk" og Heltesalens frygtindgydende supernaturalisme, og afslutningsvis de mange fornemme sjældenheder, synlige beviser på verdens mangfoldighed, menneskets opfindsomhed og naturens uendelige variationer.

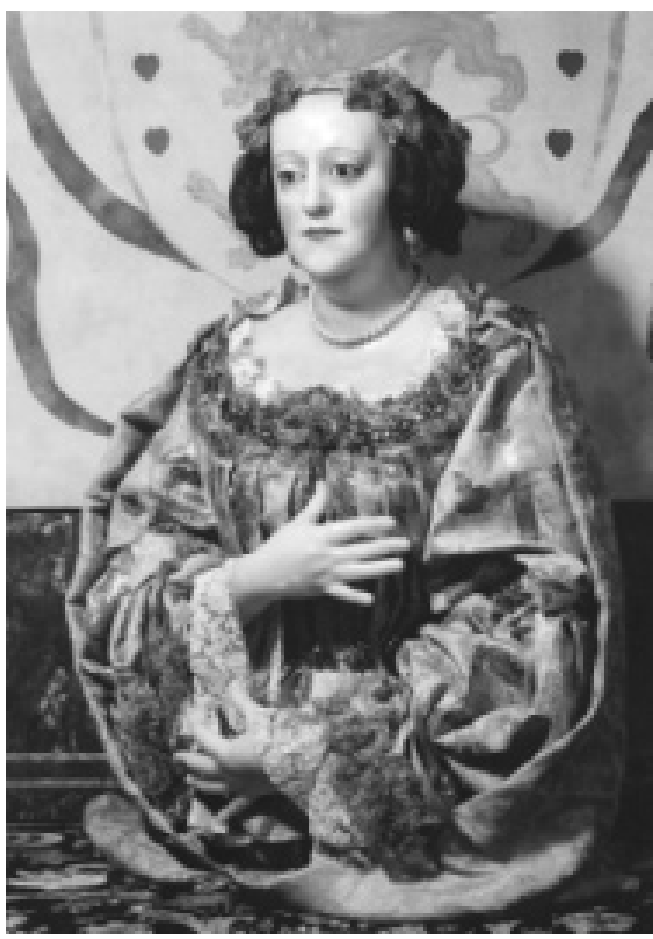

Fig. 7. Voksbuste af Dronning Sophie Amalie med dragt af silke og kniplinger (hojde 87,4 cm.). Busten er fra ca. 1670 og udforelsen er tilskrevet Antoine Benoist. Busten, som nu befinder sig på Rosenborg, var placeret $i$ Kunstkammerets Heltesal. Kilde: www.rosenborgslot.dk

\section{KUNSTKAMMERET SOM DANNELSESRITUAL}

1600- og 1700-tallets kunstkammerritualer var langt fra entydige. Hvor kongerutens iscenesættelser skulle positionere kongen som en værdig fyrste og hersker, har publikumsruten snarere været tilrettelagt med henblik på at stimulere samtidens begejstring for usædvanlige og nydelsesbetonede visuelle oplevelser.

Jeg vil afslutningsvis diskutere, hvorledes disse to iscenesættelser kan anskues som egentlige dannelsesritualer i forhold til hhv. 
den sene aristokratiske dannelse, som den kom til syne under enevælden, og den tidlige borgerlige dannelse, som voksede frem i samme periode.

\section{Aristokratisk dannelse}

Forestillingen om adelsmennesket som værende kendetegnet ved en særlig nobel opførsel blev først beskrevet i renæssancens Italien, hvor bl.a. Baldasarre Castiglione fremhævede det at betragte kunstskatte som en naturlig del af uddannelsen af de unge mænd (Illeris 2002: 75-76). Private samlinger af kunstskatte voksede frem beregnet på fyrstens humanistiske studium af sammenhængen mellem naturen, kunsten, mennesket og i sidste ende Gud (Bredekamp 1993/1995). I 1600-tallet flyttedes dannelsens fokus fra det lærde til det mere spektakulære, en proces som kulminerede med absolutismen, hvor tingenes mening ikke længere bestod i deres skjulte forbindelsesled til Gud, men i deres karakter af selvindlysende tegn. Hvor fyrster og konger tidligere havde indrettet private studerekamre, fordrede enevælden af Guds nåde en ritualiseret gennemsigtighed, der ikke gav plads til private rum (Elias 1969/1983).

En konsekvens af denne forskydning var at hofmenneskets adfærd blev performativt orienteret. Dannethed kom til at bestå i evnen til at tolke og opføre enhver handling som tegn på kongens ære og storhed. Derfor blev det nødvendigt at udvikle et dobbeltblik, hvor man gennem avanceret selvrefleksion, hele tiden skiftede register i forhold til det 'passende' $i$ en given situation.

Kunstkammerets ritualer indgik som en af mange rigt nuancerede komponenter i denne dannelse. Gennem iscenesættelsen af forskellige blikke, fungerede paraderitualet som en ypperlig mulighed for fremvisning af hofmenneskets mest subtile performative færdighe- der: på den ene side videnskabelig observation, æstetisk smag og kenderblik, på den anden side tolkningen og rammesætningen af disse blikke til kongens ære, som et led i en allesteds nærværende hyldest til hans person, hans værdighed og hans rige. Som dannelsesritual indgik kongeruten således som et raffineret led $\mathrm{i}$ adelsmandens selvrefleksive disciplinering af krop og blik. Her blev adfærden så at sige formgivet fra rum til rum. Kongen, hans følge og hans gæster måtte være i stand til at se og blive set på forskellige måder alt efter hvor på kongeruten de befandt sig: i Medalliekammeret, i Galleriet, i Heltesalen eller i en af de øvrige fire tematiske sale.

\section{BORGERLIG DANNELSE}

I Danmark som i resten af Europa var 1700tallet kendetegnet ved udkrystalliseringen af en specifik borgerlig kultur, som op gennem århundredet kom til at stå i stigende kontrast til hofkulturen. Hvor hofsamfundet var kendetegnet af minutiøse iscenesættelser af alle livets sfærer, begyndte man i den markedsøkonomisk baserede borgerkultur at skelne mellem offentlig og privat, arbejde og fritid, og besøg på Kunstkammeret blev efterhånden en aktivitet, der hørte fritiden til.

I løbet af 1700-tallet skete der endvidere en glidning i Kunstkammerets ritualiseringer, hvor paraderitualets rolle i forhold til hoffets selviscenesættelser blev mindre, mens fremviserritualets betydning langsomt voksede og kom til at udgøre en uafhængig funktion med kunstkammerforvalteren som hovedaktør. Med ham som omviser, kunne 1700-tallets nydelsessyge borgerlige publikum villigt lade sig iscenesætte som nysgerrige syns-entusiaster, der lod sig forføre af perspektivstykker, trompe l'oeil, voksfigurer og besynderlige gen- 
stande. Det glubske blik, som fremviserritualet iscenesatte, blev tilgængeligt for flere, og selvom ritualet egentlig var organiseret som en hyldest til kongen, kom det formentlig mere og mere til at medvirke til publikums forståelse af sig selv som en "offentlighed", det var forvalterens rolle at imponere og belære ved hjælp af Kunstkammerets spektakulære iscenesættelser. På den måde åbnede publikumsrollen for en forståelse af sammenhængen mellem visuel oplevelse, indsigt og viden, en forståelse som på en gang kom til at udgøre en vigtig forudsætning for - og modsætning til de fremvoksende borgerlige dannelsesidealer.

Stafford (1994: XXVI) fremhæver oplysningstiden som en periode kendetegnet ved et modsætningsforhold mellem "spectacle or gaping at heaped-up goods, and observation, or the reasoned apprehension of phenomena”. På den ene side værdsatte man det nysgerrige og imponerede blik, som Kunstkammerets iscenesættelser lagde op til, på den anden side opfordredes publikum i stigende grad til "sund" skepsis, som reducerede Kunstkammerets komplekse iscenesættelser til en uordentlig samling besynderligheder. ${ }^{19}$ Som dannelsesideal bliver den skuelyst og visuelle opdragelse, der forbindes med publikumsrutens iscenesættelser, efterhånden afløst af den klassiske museumsformidlings ritualer, organiseret omkring rundgangen og det kritisk-kontemplative kenderblik.

\section{Perspektivering: KunstKammeret set I ET NUTIDIGT FORMIDLINGSPERSPEKTIV}

Meget er efterhånden blevet skrevet om den manglende forståelse kunstkammertanken har været udsat for i perioden efter enevældens opløsning, hvor den moderne, borgerliggjorte vidensorganisering for alvor blev domineren- de (se fx Hooper-Greenhill 1992). I introduktionen til sin bog plæderer Barbara Stafford kraftigt for, at vi lader os inspirere af 1700-tallets avancerede visuelle dannelsesformer i udviklingen af nye, former for "visual education", som kan matche børn og unges fortrolighed med interaktive multimedialt baserede visuelle verdener (Stafford 1994: xxi-xxv).

Jeg finder at Kunstkammerets dannelsesritualer kan give inspiration til eksperimenterende formidlingsformer i nutidens museer. I forlængelse af nyere pædagogisk forsknings fokus på begreberne performativitet og performance (se fx Illeris 2003, 2004) kan det fx meget vel tænkes at paraderitualets subtile disciplinering af krop og blik kunne anvendes som udgangspunkt for museumspædagogiske tiltag, baseret på forskellige former for iscenesættelse. Således ville pædagogiske iscenesættelser baseret på kunstkammerets dannelsesritualer kunne anvendes til problematiseringer af den traditionelle kritisk-kontemplative beskuerrolle ved at give deltagerne mulighed for at performe mere dynamiske og aktivt undersøgende subjektpositioner, blikformer og bevægelsesmønstre end dem, der sædvanligvis lægges op til i museumsformidlingen.

\section{NOTER:}

1. I dag ville man beskrive placeringen som værende mellem Rigsdagsgården, hvor trappen ind til Folketinget ligger, og det Kgl. Biblioteks Have. Bygningen er siden sin opførelse flere gange blevet gennemgribende ændret såvel indvendig som udvendigt, så det i dag stort set kun er ydermurene, der står tilbage af den oprindelige konstruktion.

2. I 1780 'erne opførtes en ca. $21 \mathrm{~m}$. lang tilbygning 
i forlængelse af den oprindelige bygning mod det nuværende Tøjhus. Både tilbygningens første og anden etage blev anvendt til en udvidelse af biblioteket. (Schiøtt 1908: 17-18)

3. Jeg slutter figurernes højde ud fra facadebillederne fra hhv. 1702 (Udsnit fra Hoffmans dekorerede Københavnskort) og 1748 (fig. 1).

4. Fx indeholdt ærkehertug Ferdinands firefløjede anlæg på Schloss Ambras ved Innsbruck samme opdeling i tøjhus, bibliotek og kunstkammer som den danske bygning (Mordhorst 2003: 34, note 76 ).

5. I forhold til lignende bygninger ved andre europæiske hof blev det danske kunstkammer opført og indrettet forholdsvis sent. Hos de danske konger var 'kunstkammersager', sammen med øvrige skatte blevet opbevaret i private kamre på de kongelige slotte, oftest kongens drejerkammer ved siden af sovegemakkerne. Efterhånden som de kongelige samlinger voksede blev der dog brug for flere rum til opbevaring af disse, og i 1653 udvidede Frederik III sit drejerkammer på Københavns Slot med ni nyindrettede rum i slottets sydfløj og skabte dermed det første danske kunstkammer (www.kunstkammer.dk).

6. Artiklen er et led i en bredere genealogisk undersøgelse af rituelle iscenesættelser omkring det at betragte kunstgenstande. Projektet støttes af NOVO Nordisk Fonden.

7. Når Duncan anvender begrebet "ritual" sker det med henvisning til det brede ritualbegreb, som blev teoretiseret i 1970 'erne. Her introducerede bl.a. antropologerne Sally Falk Moore og Barbara Myerhoff (1977) begrebet "verdsligt ritual" med henblik på at analysere visse former for adfærd i moderne vestlige samfund. I modsætning til det religiøse ritual, er det verdslige ritual alene genkendeligt på sine formelle karakteristika, hvoraf de væsentligste kan beskrives som følger: Ritualet består i en særlig handlingssekvens, som indbefatter en begyndelse og en slutning og som kan gentages. Deltagerne i ritualet indtager på forhånd bestemte og genkendelige positioner, som kan markeres gennem særlig påklædning og/eller særlige placeringer i rummet. Ritualet indeholder endvidere et særligt bevægelsesmønster eller "koreografi" - fx museumsgæsternes gang fra kunstværk til kunstværk (Klein 1995: 14-18).

8. Væsentligste referencer er her Liisberg 1897 , Schiøtt 1908, Andrup 1933, Nielsen 1988, Gundestrup 1991, Mordhorst 2003.

9. Se fx Bencard 1993, 1994, Hein 2001, 2002, Gundestrup 2004, de la Fuente 2005, Tøndborg 2005.

10. Pædagogisk antropologi er et forholdsvis nyt fagområde, som bl.a. undersøger forhold mellem rum, krop og pædagogik. I 2001 oprettedes Institut for Pædagogisk Antropologi ved Danmarks Pædagogiske Universitet. Et af forskningsfelterne ved instituttet er visuel kultur som pædagogisk fagområde, hvor museumspædagogik udgør et væsentligt forskningsfokus.

11. Bygningen var som nævnt opført uden tværmure. Derfor måtte Kunstkammerets gulv og loft anbringes i hængesøjler som blev fastgjort i tagkonstruktionen, og man måtte lægge trægulv i stedet for marmor for at det ikke skulle blive for tungt (Mogensen 2001: 40).

12. På fjerde etage under loftet indrettedes yderligere et kammer til modeller. Dette kammer er ikke medtaget i analyserne i denne artikel, da det ville have været for omfattende.

13. En væsentlig indikation om at Kunstkammeret formentlig har været indrettet med ensfarvede vægge er, at Frederik III efter ganske kort tid fik overmalet de fantasifulde dekorationer, der i første omgang kom til at pryde kunstkammerværelserne på slottet, til fordel for bemalinger i en enkelt farve I hvert rum. (www.kunstkammer.dk). Man kan derfor med rimelighed forestille sig, at man har ønsket at bibeholde en sådan enkelthed i rumdekorationen på kunstkammeretagen. 
14. En rekonstruktion af nogle kunstkammerskabe fra naturaliekabinettet på Københavns Slot blev foretaget I forbindelse med Nationalmuseets udstilling Museum Europa. Skabene var her malet lysegrønne udvendigt og lysegrå indvendigt og var udstyret med gennemsigtigt, moderne glas. De ligger således temmelig langt fra Andrups oven for citerede beskrivelse, men kan muligvis give en idé om, hvorledes skabene kan have set ud i 1700-tallet.

15. Også Medalliekammeret og Perspektiv-Kammeret havde stuklofter.

16. Den berejste Frederik III kan fx have hentet inspiration i Fontainebleau ved at besøge Francois I's berømte renæssancegalleri fra 1566 og Henrí IV's Galerie des Cerfs og Galerie de Diane fra ca. 1600. I Palais Luxembourg kan han endvidere have set Maria de’ Medicis ikke længere eksisterende galleri fra 1622 med scener fra dronningens liv (Prinz 1977/1988).

17. Hvor ofte kongerne rent faktisk besøgte Kunstkammeret vides der ikke så meget $\mathrm{om}$. Gængse royale historiebøgers fortællinger vil, at ingen af kongerne efter "den lærde" Frederik III, som ikke nåede at se bygningen færdigindrettet inden sin død i 1670, interesserede sig særlig meget for hverken bibliotek eller Kunstkammer (se fx Bisgaard m.fl. 2004). Ikke desto mindre dokumenterer dagbøger skrevet af Frederik III's søn Christian $\mathrm{V}$, at han ind imellem besøgte biblioteket, og at han "for sidste gang i sit Liv, den 13. februar 1699 [...] 'begav sig til Biblioteket og Kunstkammeret"' (Molbech 1848: 232). Det var også Christian V, der i 1696 fik udgivet pragtværket Museum Regium med inventarliste og afbildninger af kammerets vigtigste genstande. Denne udgivelse medvirkede til at skaffe kammeret international bevågenhed, og gjorde det til en vigtig attraktion, såvel for hoffets private gæster som for et tilrejsende publikum.

18. Denne ordning havde, som diskuteret af Mogens
Benchard (1993), en række lighedspunkter med

anbefalingerne i Samuel Quicchebergs museumsteori fra 1565.

19. I sit tilbageblik fra 1897 anfører Bering Liisberg ligefrem "Stoffets Uensartethed og Mangel på indre Sammenhæng" som den væsentligste hindring for Kunstkammerets "folkeoplysende betydning" (Liisberg 1897: 151).

\section{LITTERATUR:}

Andrup, Otto: Den Kongelige Samling paa Rosenborg gennem hundrede Aar. København 1933.

Bencard, Mogens: Museerne og Verdensordenen Kunstkammerets opståen og grundidé. Nordisk Museologi. Nr. 1, 1993: 3-16.

Bencard, Mogens: Kunstkammers and Museums. Nordisk Museologi. Nr. 1, 1994: 21-24.

Bisgaard, Lars m.fl.: Danmarks konger og dronninger. København 2004.

Bredekamp, Horst: The Lure of Antiquity and the Cult of the Machine. The Kunstkammer and the Evolution of Nature, Art and Tecnology. Princeton 1995. Oversat fra: Antikensehnsucht un Maschinenglauben. Verlag Klaus Wagenbach 1993.

Burke, Peter: The historical anthropology of early modern Italy. London 1987.

Det kongelige Bibliotek: Det kongelige Bibliotek - et hus på Slotsholmen. København 1993.

Duncan, Carol: Civilizing Rituals. Inside Public Art Museums.London 1995.

Elias, Norbert: The Court Society. Oxford 1983. Oversat fra: Die höfische Gesellschaft. Darmstadt und Neuwied 1969.

Gundestrup, Bente: Det Kongelige danske Kunstkammer 1737. København 1991.

Gundestrup, Bente: Kunstkammeret og Albert Eckhouts malerier. Nordisk Museologi. Nr. 1, 2004: 43-58. 
Hein, Jørgen: Repræsentation eller belæring? Nordisk Museologi. Nr. 1-2, 2001: 135-170.

Hein, Jørgen: Learning versus status? Kunstkammer or Schatzkammer? Journal of the History of Collections. Vol. 14, Nr. 2, 2002: 177-192.

Hooper-Greenhill, Eilean: Museums and the shaping of knowledge. London 1992.

Illeris, Helene: Billede, padagogik og magt - postmoderne optikker $i$ det billedpadagogiske felt. Frederiksberg 2002.

Illeris, Helene: Vad kan man lära av samtidskonsten? Om konstpedagogik och bildningssyn. Konstperspektiv. Nr. 3, 2002: 32-36.

Illeris, Helene: Performative positioner i kunstpædagogik. Valör - Konstvetenskapliga studier. Nr. 4, 2003:15-28.

Illeris, Helene: Mødet som kunstværk: valg, iscenesættelse, appropriation, i: Frants Mathiesen og Tine Seligmann (red.): Mødesteder - om formidling af samtidskunst, Frederiksberg: Samfundslitteratur, 2004.

Illeris, Helene: Museums and galleries as performative sites for lifelong learning: constructions, deconstructions and reconstructions of audience positions in museum and gallery education. $\mathrm{Mu}$ seum \& Society. Nr. 1, 2006.

Klein, Barbro: Gatan är vår! Ritualer på offentliga platser. Stockholm 1995.

Lange, Ulrik: Ritual, symbol, tekst og praksis - nogle teoretiske og metodiske overvejelser. I: Lange, Ulrik (red.): Ritualernes magt. Ritualer i Europaisk historie 500-2000. Roskilde 2002: 13-46.

Liisberg, H.C. Bering: Kunstkammeret - dets stiftelse og aldre historie. København 1897.

Lund, Hakon: Slotsholmen. I: København for og nuog aldrig, bd. 1. København 1996.

Mauriès, Patrick: Das Kuriositätenkabinett. Köln 2002.

Mogensen, Margit: Rigsarkivet. Husene på Slotsholmen. Statens Arkiver 2001.

Molbech, C.: Kong Christian den Femtes egenhandige Dagboger Kiøbenhavn 1848.
Moore, Sally Falk and Myerhoff, Barbara G. (eds.): Secular ritual: forms and meanings. Amsterdam 1977.

Mordhorst, Camilla: Genstandsfortallinger - Fra Museum Wormianum til de moderne museer. Ph.d.-afhandling. Roskilde Universitetscenter/Nationalmuseet 2003.

Nielsen, Flemming Steen: Fra fyrsteligt raritetskabinet til offentligt museum. En undersogelse af museumsvesenet og dets rolle i kulturkampen i Danmark under enevalden. Specialeopgave. Københavns Universitet 1988.

Olden-Jørgensen, Sebastian: Hofkultur, ritual og politik i Danmark 1536-1746. I: Lange, Ulrik (red.): Ritualernes magt. Ritualer i Europeisk historie 500-2000. Roskilde 2002: 47-76.

Pedersen, Eva de la Fuente: Cornelius Norbertus Gijsbrechts og kunstkammerets perpectivkammer. Nordisk Museologi. Nr 1, 2005: 69-86.

Prinz, Wolfram: Galleria - storia e tipologia di uno spazio architettonico. Ferrara 1988. Oversat fra: Die Entstehung der Galerie in Frankreich und Italien. Berlin 1977.

Regnard, J.-F.: Rejse i Danmark 1681. Oversat og forsynet med noter af Svend Emerson-Bremer. København 1909.

Scheicher, Elisabeth: The Collection of Archduke Ferdinand II at Schloss Ambras: It's Purpose, Composition and Evolution. I: Impey, Oliver og McGregor, Arthur (eds.): The Origins of Museums. London 1985.

Schiøtt, Fr.: Kong Frederik III's Biblioteks- og Kunstkammer-Bygning. Kjøbenhavn 1908.

Seelig, Lorenz: The Munich Kunstkammer, 15651807. I: Impey, Oliver og McGregor, Arthur (eds.): The Origins of Museums. London 1985.

Sirén, Osvald: Nicodemus Tessin D.Y:S studieresor i Danmark, Tyskland, Holland, Frankrike och Italien. Anteckningar, brefoch ritningar. Stockholm 1909.

Stafford, Barbara Maria: Artful Science: Enlightenment 
Entertainment and the Eclipse of Visual Education.

Massachusetts 1994.

Turah, Laurids de: Hafnia Hodierna. Kiøbenhavn

1748. Genudgivet med efterskrift af Steffen Linvald. København 1967.

Tøndborg, Britta: From specimens, curiosities and illustrations to representatives of the history of art. Nordisk Museologi. Nr 1, 2005: 55-68.

Villadsen, Villads: Statens Museum for Kunst 18271952. København 1998.

\section{Hjemmesider:}

www.kunstkammer.dk www.rosenborgslot.dk

* Helene Illeris is Associate Professor of Art and Visual Culture at the Danish University of Education, Department for Educational Anthropology. She holds an M.A. degree in Art Theory from the Royal Danish Academy of Fine Arts and a Ph.D. in Art Education from the Danish University of Education.

Address: Danmarks Padagogiske Universitet, Institut for Pedagogisk Antropologi, Tuborgvej 164

DK-2400 Copenhagen NV, Denmark

E-mail:illeris@dpu.dk

Phone (work) + 4588889823

Fax (work): + 4588889706 